\title{
Student Perception of Interest in Learning and its Impact on Online Learning of Public Health Study Program, University of Muhammadiyah Jakarta
}

\author{
${ }^{1}$ Indah Nofita, ${ }^{2}$ Karimah Azzahra, ${ }^{3}$ Lentera Mahameru Kaffah, ${ }^{4}$ Nabilah Nur Haenisa, ${ }^{5}$ Munaya \\ Fauziah \\ 1,2,3,4,5 Faculty of Public Health, Muhammadiyah University of Jakarta \\ K.H. Ahmad Dahlan St, Cireundeu, Ciputat, South Jakarta, 15419 \\ E-mail: indahnovita494@gmail.com
}

\begin{abstract}
In Indonesia, a large-scale social restriction policy or commonly known as PSBB has been implemented to further suppress the spread of this virus in Indonesia. The education sector is changing due to the Covid-19 pandemic. The government through the Letter of the Minister of Education and Culture Number 36962 / MPK.A / HK / 2020 concerning Online Learning and Working from Home to Prevent the Spread of Covid-19 as an effort to prevent the spread of Covid-19. The Learning System has changed from face-to-face to online where this research was conducted at the Faculty of Public Health, the University of Muhammadiyah Jakarta in 2021. The objective of this study was to determine student perceptions regarding online learning during the Covid-19 period. Descriptive research method design with a qualitative approach with phenomenological methods. The sample in this study was four (4) students consisting of one second semester, one fourth semester, and two sixth semesters. This study wants to explore the phenomena experienced by students in online learning during the COVID-19 pandemic. The variables studied include behavior, perception, motivation, action and some of them are grouped into learning impacts, physical linkages, infrastructure, and holistic Islamic practices experienced by students in online learning. The result from The impact of learning is that students feel less interested in learning, less effective, and less understanding. From a physical point of view, eye fatigue is felt, from facilities and infrastructure students feel signal barriers when doing online learning from parental support to support online learning and from Islamic practice in the learning process carried out by several lecturers, in terms of decreased motivation to learn students experience decreased motivation to learn, in terms of student satisfaction, they are not satisfied and want offline learning.
\end{abstract}

Keywords: Learning, Impact, Perception, Online, Interest 
E-ISSN: 2808-5361 http://e-journal.fkmumj.ac.id/
Proceeding The First Muhammadiyah InternasionalPublic Health and Medicine Conference

\section{INTRODUCTION}

Covid-19 is a new disease that has never been identified in humans. The cause of Covid-19 is called the Sars CoV-2 virus. Covid-19 has become a pandemic disease that has attacked 223 countries in the world. Based on data from the World Health Organization (WHO) on April 2, 2021, it recorded 129,215,179 confirmed cases and 2,820,098 deaths worldwide. The relatively fast spread of Covid-19 Given the very fast spread of the disease. Covid-19 cases in Indonesia until April 2, 2021 recorded 1,523,179 confirmed cases, 1,361,017 recovered cases and 41,151 cases died. (WHO, 2021)

In Indonesia, a large-scale social restriction policy or commonly known as PSBB has been implemented to further suppress the spread of this virus. The education sector is changing due to the Covid-19 pandemic. The government through the Letter of the Minister of Education and Culture Number 36962 / MPK.A / HK / 2020 concerning Online Learning and Working from Home to Prevent the Spread of Covid-19 as an effort to prevent the spread of Covid-19. The learning system has changed from face-to-face to online. Online learning is that virtually through available virtual applications. However, online learning must still pay attention to the competencies to be taught. Online learning must be planned according to the interests and efficiency of the students at the school.

Interest and motivation to learn are two psychological factors that have been empirically proven to have a significant influence on student's academic achievement at school. Students who have high learning interest and motivation are usually characterized by good academic scores, have structured study habits, have a good understanding of each reading, have high self-efficacy, and have high learning performance. According to research conducted by (Priyastuti and Suhadi, 2020).

It is known that the average value of respondents' perceptions of aspects of the teaching and learning process is 15.41 with a standard deviation (SD) of 3.92. Therefore, a value that is above or equal to 16 is interpreted as a positive perception, while a smaller value $(<16)$ is interpreted as a negative perception.

Based on other studies, the results showed that the level of student satisfaction in online use reached $67 \%$, students were able to do online learning $82 \%$, and students supported online learning 72\%. (Jatmoko and Faizun, 2020).

This online learning affects an interest in learning because students become easily bored when online learning takes place. students feel that face-to-face lectures or being in class, as usual, are considered more optimal and the delivery of material given by lecturers is much more acceptable than online or online lectures which have several obstacles and obstacles for some students so far. Due to the many obstacles or obstacles, the government should be able to make it a benchmark for the development of education by students, especially students in Indonesia. 
E-ISSN: 2808-5361 http://e-journal.fkmumj.ac.id/
Proceeding The First

Muhammadiyah Internasional-

Public Health and Medicine

Conference

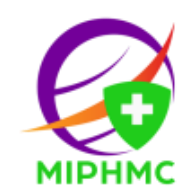

\section{METHODS}

This study aims to determine the perceptions of students of the Public Health Study Program, Faculty of Public Health, the University of Muhammadiyah Jakarta regarding online learning during the Covid-19 period in 2021. This type of qualitative research with a phenomenological approach to data collection comes from in-depth interviews which are then copied in the form of words to four informants. different semesters of study. The source triangulation design approach was carried out on four informants to determine Student Perceptions About Online Learning on Student Interest in Public Health Study Program, Muhammadiyah University, Jakarta.

This study uses a qualitative method by collecting data from in-depth interviews expressed in words or writing. This research is, research conducted on students of the Public Health Study Program. And take a sample of 4 students. The research period lasted for 2 months, namely AprilMay 2021.

4 informants were interviewed in May 2021, the interviews were conducted via mobile phones to avoid contact during the pandemic. Sources of information or informants in this study were students of the Faculty of Public Health, Muhammadiyah University, Jakarta. The informants who will be conducting in-depth interviews are 4 informants who have a perception about Online Learning on Interest in Learning during this covid-19 pandemic. The informants were selected based on the availability of adequacy criteria, representation in explaining the answers to the questions in this study, the informants had the initials MR (21) semester 6, AR (21) semester 6, L (18) semester 2, AM (19) semester 4.

There are two types of data sources used in this study, namely primary data and secondary data. Primary data was obtained from the answers of the informants during in-depth interviews, specifically to answer research questions. As for the secondary data obtained from the results of data collection techniques that support primary data. This study was obtained from the author's observations of literature studies related to this research.

To maintain the validity of the data, to determine the validity of the data in this study, one triangulation was used, namely the Triangulation Method. Source triangulation was carried out using in-depth interviews with predetermined informants using research instruments in the form of interview guidelines. Method triangulation is done using in-depth interviews and observations from literature studies. Researchers use this triangulation to ensure the accuracy of the collected informant data. Researchers discuss the findings of in-depth interviews and data observations with the research team and the expert.

The processing and analysis of qualitative data in this study were carried out by rewriting the data where the data was transferred in the written form completely without changing, adding, or 
E-ISSN: 2808-5361 http://e-journal.fkmumj.ac.id/
Proceeding The First

Muhammadiyah InternasionalPublic Health and Medicine

Conference

subtracting the information contained in the interview notes. Then a descriptive data analysis was carried out so that conclusions were obtained from the data that had been processed by coding each resource person's answers contained in table 1.

Table 1. Results and Data Analysis

\begin{tabular}{|c|c|c|c|c|c|}
\hline Topic & Meaning unit & Code & Sub category & Category & Theme \\
\hline $\begin{array}{l}\text { How many } \\
\text { students are } \\
\text { in your } \\
\text { class? }\end{array}$ & $\begin{array}{ll}\text { 1. } & 62 \text { People } \\
\text { 2. } & 60 \text { People } \\
\text { 3. } & 60 \text { People } \\
\text { 4. } & 52 \text { People }\end{array}$ & $\begin{array}{l}\text { Amount of students } \\
\text { in } 1 \text { class }\end{array}$ & $\begin{array}{l}\text { The difference in } \\
\text { number in } 1 \text { class }\end{array}$ & $\begin{array}{l}\text { Varied } \\
\text { amount }\end{array}$ & $\begin{array}{l}\text { Perception } \\
\text { of interest } \\
\text { in learning }\end{array}$ \\
\hline $\begin{array}{l}\text { Explain how } \\
\text { the impact } \\
\text { of covid-19 } \\
\text { on the } \\
\text { learning } \\
\text { process? }\end{array}$ & 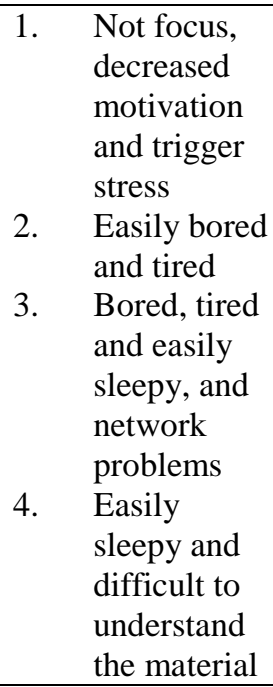 & $\begin{array}{l}\text { 1. Not eager to learn } \\
\text { 2. The impact of } \\
\text { online learning is } \\
\text { easy to get bored } \\
\text { and tired } \\
\text { 3. Easily bored, } \\
\text { sleepy, tired } \\
\text { 4. A little confusing } \\
\text { when studying } \\
\text { online }\end{array}$ & Interest to learn & $\begin{array}{l}\text { Impact of } \\
\text { online } \\
\text { learning }\end{array}$ & $\begin{array}{l}\text { Perception } \\
\text { of interest } \\
\text { in learning }\end{array}$ \\
\hline $\begin{array}{l}\text { How do you } \\
\text { feel about } \\
\text { the current } \\
\text { learning } \\
\text { process? }\end{array}$ & $\begin{array}{ll}\text { 1. } & \text { lecturers } \\
\text { must be able } \\
\text { to make } \\
\text { students not } \\
\text { bored by } \\
\text { making } \\
\text { quizzes } \\
\text { There are } \\
\text { good and } \\
\text { bad things } \\
\text { about it, but } \\
\text { I just take it } \\
\text { and enjoy it. } \\
\text { It's } \\
\text { comfortable } \\
\text { because the } \\
\text { distance } \\
\text { learning } \\
\text { process is } \\
\text { only in front } \\
\text { of the } \\
\text { screen, but } \\
\text { I'm bored of } \\
\text { not being } \\
\text { able to meet }\end{array}$ & $\begin{array}{l}\text { 1. There must be an } \\
\text { interest in } \\
\text { teaching } \\
\text { 2. The online } \\
\text { learning process } \\
\text { can be while } \\
\text { taking } \\
\text { 3. Just be } \\
\text { comfortable. The } \\
\text { achievement of } \\
\text { understanding } \\
\text { depends on the } \\
\text { level of difficulty } \\
\text { of the course. } \\
\text { 4. less effective and } \\
\text { experienced } \\
\text { many obstacles in } \\
\text { the online } \\
\text { learning process }\end{array}$ & $\begin{array}{l}\text { Disinterest and } \\
\text { lack of } \\
\text { understanding } \\
\text { during online } \\
\text { learning }\end{array}$ & $\begin{array}{l}\text { Impact of } \\
\text { online } \\
\text { learning }\end{array}$ & $\begin{array}{l}\text { Perception } \\
\text { of interest } \\
\text { in learning }\end{array}$ \\
\hline
\end{tabular}




\begin{tabular}{|c|c|c|c|c|c|}
\hline Topic & Meaning unit & Code & Sub category & Category & Theme \\
\hline & $\begin{array}{l}\text { friends in } \\
\text { person } \\
\text { less } \\
\text { effective } \\
\text { because } \\
\text { there are } \\
\text { obstacles } \\
\text { such as } \\
\text { internet } \\
\text { connection } \\
\text { or signal } \\
\text { loss. }\end{array}$ & & & & \\
\hline $\begin{array}{l}\text { Since when } \\
\text { did the } \\
\text { current } \\
\text { learning } \\
\text { method (e- } \\
\text { learning) be } \\
\text { applied? }\end{array}$ & $\begin{array}{l}\text { 1. } \begin{array}{l}\text { Since covid } \\
\text { March } 2019\end{array} \\
\text { 2. } \begin{array}{l}\text { Since the } \\
\text { news of } \\
\text { covid, the } \\
\text { cases have } \\
\text { been high if } \\
\text { I'm not } \\
\text { mistaken. } \\
\text { 3. } \begin{array}{l}\text { Since the } \\
\text { middle of } \\
\text { covid } 19\end{array} \\
\text { Since the } \\
\text { first } 2 \text { weeks } \\
\text { of covid } 19 \\
\text { entering } \\
\text { Indonesia }\end{array}\end{array}$ & $\begin{array}{l}\text { 1. March } 2019 \\
\text { 2. since the high } \\
\text { cases of covid } \\
\text { 3. End of March } \\
2020\end{array}$ & $\begin{array}{l}\text { When the covid } \\
\text { pandemic enters } \\
\text { Indonesia }\end{array}$ & $\begin{array}{l}\text { Early stages } \\
\text { of online } \\
\text { learning }\end{array}$ & $\begin{array}{l}\text { Perception } \\
\text { of interest } \\
\text { in learning }\end{array}$ \\
\hline $\begin{array}{l}\text { Is the } \\
\text { learning } \\
\text { process } \\
\text { undertaken } \\
\text { currently } \\
\text { effective in } \\
\text { achieving } \\
\text { the } \\
\text { expectations } \\
\text { of the } \\
\text { learning } \\
\text { activities? }\end{array}$ & 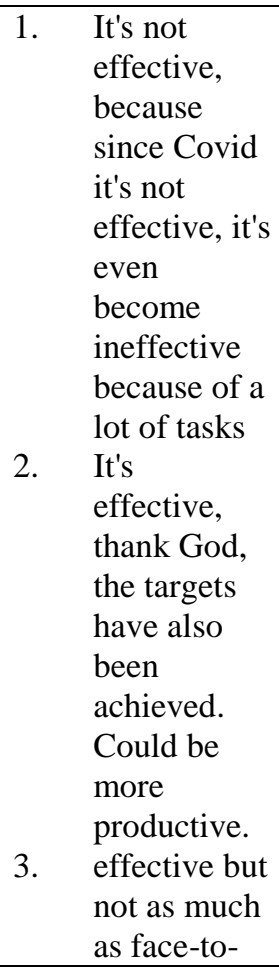 & $\begin{array}{l}\text { 1. Learning is not } \\
\text { effective and } \\
\text { does not reach } \\
\text { expectations } \\
\text { because it is just } \\
\text { a lot of work } \\
\text { 2. effective, and } \\
\text { more productive } \\
\text { in the online } \\
\text { learning process } \\
\text { 3. effective but not } \\
\text { as much as face- } \\
\text { to-face. } \\
\text { 4. feel less effective } \\
\text { doing online } \\
\text { learning }\end{array}$ & $\begin{array}{l}\text { Ineffectiveness in } \\
\text { online learning }\end{array}$ & $\begin{array}{l}\text { Stages of the } \\
\text { online } \\
\text { learning } \\
\text { process }\end{array}$ & $\begin{array}{l}\text { Perception } \\
\text { of interest } \\
\text { in learning }\end{array}$ \\
\hline
\end{tabular}




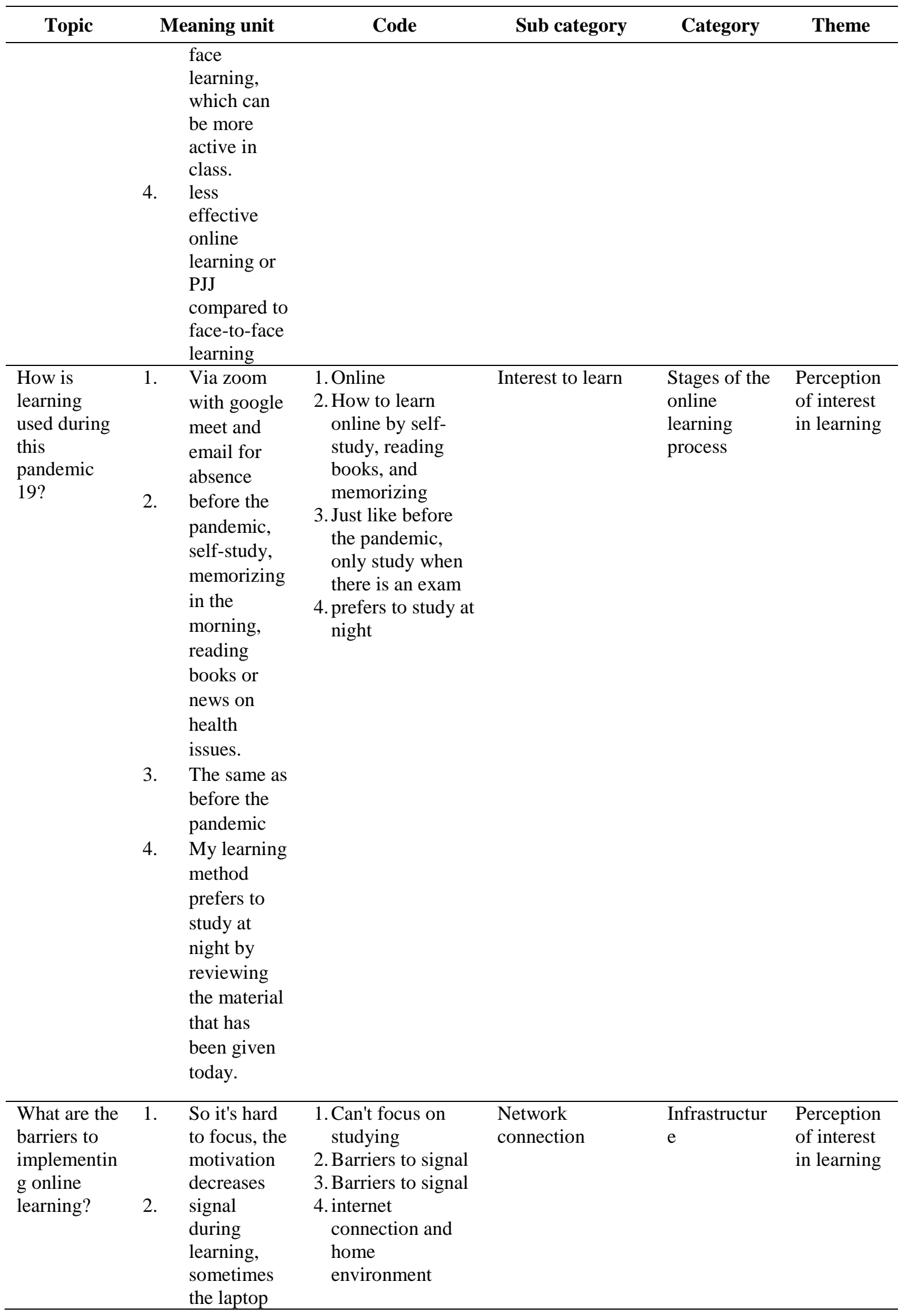


E-ISSN: 2808-5361 http://e-journal.fkmumj.ac.id/
Proceeding The First

Muhammadiyah InternasionalPublic Health and Medicine

Conference

\begin{tabular}{|c|c|c|c|c|c|}
\hline Topic & Meaning unit & Code & Sub category & Category & Theme \\
\hline & $\begin{array}{l}\text { also hangs } \\
\text { because it } \\
\text { has been } \\
\text { used for } \\
\text { hours on } \\
\text { assignments. } \\
\text { If there is a } \\
\text { problem } \\
\text { with the } \\
\text { internet, you } \\
\text { must go in } \\
\text { and out of } \\
\text { zoom. So } \\
\text { you like to } \\
\text { miss the } \\
\text { material } \\
\text { delivered by } \\
\text { the lecturer } \\
\text { connection } \\
\text { from the } \\
\text { internet that } \\
\text { is not very } \\
\text { stable and } \\
\text { the home } \\
\text { environment } \\
\text { is } \\
\text { sometimes } \\
\text { noisy so that } \\
\text { it hinders } \\
\text { the learning } \\
\text { process }\end{array}$ & & & & \\
\hline $\begin{array}{l}\text { Did you feel } \\
\text { physically } \\
\text { exhausted } \\
\text { during this } \\
\text { online } \\
\text { learning? }\end{array}$ & 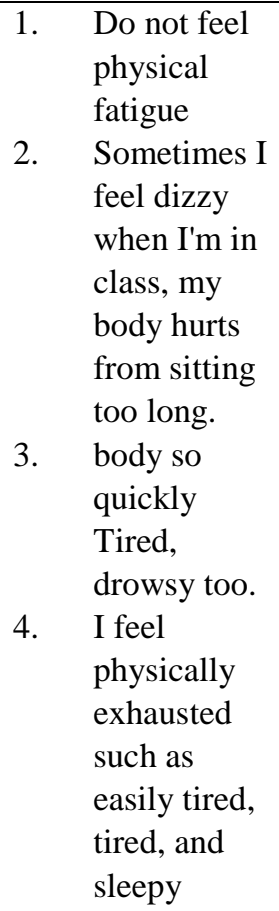 & $\begin{array}{l}\text { 1. No physical } \\
\text { fatigue } \\
\text { 2. The occurrence } \\
\text { of physical } \\
\text { fatigue during } \\
\text { online learning } \\
\text { 3. The body feels } \\
\text { tired and sleepy } \\
\text { 4. physical } \\
\text { exhaustion both } \\
\text { tired and sleepy }\end{array}$ & Physical fatigue & $\begin{array}{l}\text { Impact of } \\
\text { online } \\
\text { learning }\end{array}$ & $\begin{array}{l}\text { Perception } \\
\text { of interest } \\
\text { in learning }\end{array}$ \\
\hline
\end{tabular}




\begin{tabular}{|c|c|c|c|c|c|}
\hline Topic & Meaning unit & Code & Sub category & Category & Theme \\
\hline $\begin{array}{l}\text { Are you } \\
\text { experiencing } \\
\text { a decrease in } \\
\text { motivation } \\
\text { to study? }\end{array}$ & 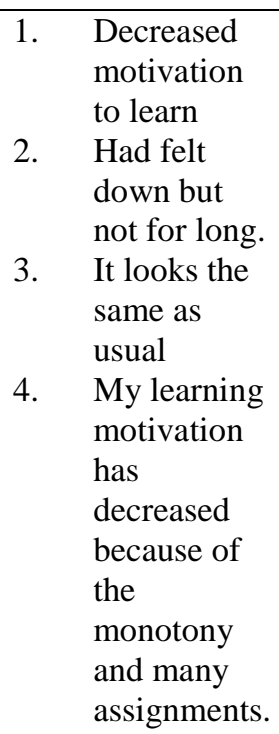 & $\begin{array}{l}\text { 1. Not motivated to } \\
\text { learn } \\
\text { 2. Decreased } \\
\text { motivation in } \\
\text { learning } \\
\text { 3. There is no } \\
\text { decrease in } \\
\text { learning } \\
\text { motivation } \\
\text { 4. My learning } \\
\text { motivation has } \\
\text { decreased } \\
\text { because of the } \\
\text { monotony and } \\
\text { many } \\
\text { assignments. }\end{array}$ & Interest to learn & $\begin{array}{l}\text { Impact of } \\
\text { online } \\
\text { learning }\end{array}$ & $\begin{array}{l}\text { Perception } \\
\text { of interest } \\
\text { in learning }\end{array}$ \\
\hline $\begin{array}{l}\text { What is your } \\
\text { emotional } \\
\text { state when } \\
\text { you take } \\
\text { online } \\
\text { learning? }\end{array}$ & 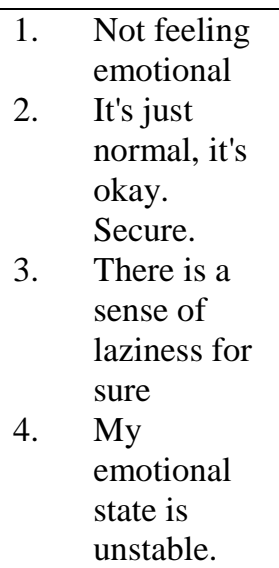 & $\begin{array}{l}\text { 1. Do not like to be } \\
\text { angry } \\
\text { 2. normal emotions } \\
\text { 3. Laziness and } \\
\text { panic arise when } \\
\text { there are many } \\
\text { tasks. hard to } \\
\text { divide the time } \\
\text { 4. unstable } \\
\text { emotional state }\end{array}$ & Mental state & $\begin{array}{l}\text { Impact of } \\
\text { online } \\
\text { learning }\end{array}$ & $\begin{array}{l}\text { Perception } \\
\text { of interest } \\
\text { in learning }\end{array}$ \\
\hline $\begin{array}{l}\text { What } \\
\text { learning } \\
\text { methods do } \\
\text { you prefer } \\
\text { online/offlin } \\
\text { e? }\end{array}$ & $\begin{array}{l}\text { 1. } \begin{array}{l}\text { Want to go } \\
\text { offline, } \\
\text { because } \\
\text { when } \\
\text { learning is } \\
\text { easier to } \\
\text { understand } \\
\text { Over time I } \\
\text { prefer to be } \\
\text { online, } \\
\text { rather than } \\
\text { online. } \\
\text { Likes offline } \\
\text { and online } \\
\text { prefers to be } \\
\text { offline } \\
\text { because } \\
\text { there are no } \\
\text { obstacles }\end{array}\end{array}$ & $\begin{array}{l}\text { 1. It's better to learn } \\
\text { offline } \\
\text { 2. Have the sense to } \\
\text { continue learning } \\
\text { online } \\
\text { 3. Prefer offline and } \\
\text { online methods } \\
\text { 4. prefer offline } \\
\text { learning over } \\
\text { online }\end{array}$ & Interest to learn & outcome & $\begin{array}{l}\text { Perception } \\
\text { of interest } \\
\text { in learning }\end{array}$ \\
\hline
\end{tabular}




\begin{tabular}{|c|c|c|c|c|c|}
\hline Topic & Meaning unit & Code & Sub category & Category & Theme \\
\hline $\begin{array}{l}\text { Are you } \\
\text { satisfied } \\
\text { with the } \\
\text { results of } \\
\text { online } \\
\text { learning? }\end{array}$ & $\begin{array}{ll}\text { 1. } & \text { Not satisfied } \\
\text { 2. } & \begin{array}{l}\text { good } \\
\text { enough }\end{array} \\
\text { 3. } & \begin{array}{l}\text { So far it's } \\
\text { been quite }\end{array} \\
\text { satisfactory } \\
\text { 4. } & \text { was quite } \\
\text { satisfied. }\end{array}$ & $\begin{array}{l}\text { 1. Less effective } \\
\text { online } \\
\text { 2. satisfied with } \\
\text { learning } \\
\text { outcomes when } \\
\text { learning online } \\
\text { 3. It's quite } \\
\text { satisfying } \\
\text { 4. feel quite } \\
\text { satisfied } \\
\end{array}$ & Interest & outcome & $\begin{array}{l}\text { Perception } \\
\text { of interest } \\
\text { in learning }\end{array}$ \\
\hline $\begin{array}{l}\text { Is there } \\
\text { parental } \\
\text { support } \\
\text { during your } \\
\text { online } \\
\text { learning? }\end{array}$ & $\begin{array}{ll}\text { 1. } & \begin{array}{l}\text { Parents } \\
\text { support } \\
\text { because } \\
\text { costs are } \\
\text { reduced, } \\
\text { my parents } \\
\text { always }\end{array} \\
\text { support me } \\
\text { no matter } \\
\text { what, } \\
\text { My parents } \\
\text { always ask } \\
\text { if the data } \\
\text { package is } \\
\text { still } \\
\text { available or } \\
\text { not } \\
\text { my parents } \\
\text { always ask } \\
\text { if I have a } \\
\text { morning } \\
\text { class or not. }\end{array}$ & $\begin{array}{l}\text { 1. Parents support } \\
\text { online learning } \\
\text { 2. Strong parental } \\
\text { support in } \\
\text { situations like the } \\
\text { current pandemic } \\
\text { 3. Parents provide } \\
\text { support in the } \\
\text { form of internet } \\
\text { facilities and help } \\
\text { remind schedules } \\
\text { 4. get support from } \\
\text { parents in the } \\
\text { form of love }\end{array}$ & Study support & Outcome & $\begin{array}{l}\text { Perception } \\
\text { of interest } \\
\text { in learning }\end{array}$ \\
\hline $\begin{array}{l}\text { Is the time } \\
\text { to pray } \\
\text { during } \\
\text { online } \\
\text { learning } \\
\text { hindered by } \\
\text { learning } \\
\text { time? }\end{array}$ & $\begin{array}{ll}\text { 1. } & \text { Unobstructe } \\
\text { d } & \begin{array}{l}\text { always pray } \\
\text { even though } \\
\text { there is }\end{array} \\
\text { online } \\
\text { learning } \\
\text { 3. } \\
\text { not hindered } \\
\text { because I } \\
\text { usually } \\
\text { adjust and } \\
\text { manage the } \\
\text { time well } \\
\text { between } \\
\text { prayer and } \\
\text { lectures. } \\
\text { Not } \\
\text { hindered } \\
\text { because it's } \\
\text { time }\end{array}$ & $\begin{array}{l}\text { 1. Not be shut-in to } \\
\text { pray } \\
\text { 2. Continue to carry } \\
\text { out worship while } \\
\text { learning online } \\
\text { 3. Customize and } \\
\text { set the time } \\
\text { 4. There is no } \\
\text { obstacle }\end{array}$ & Not be shut-in & $\begin{array}{l}\text { Stages of the } \\
\text { online } \\
\text { learning } \\
\text { process }\end{array}$ & $\begin{array}{l}\text { Perception } \\
\text { of interest } \\
\text { in learning }\end{array}$ \\
\hline
\end{tabular}


E-ISSN: 2808-5361 http://e-journal.fkmumj.ac.id/
Proceeding The First

Muhammadiyah InternasionalPublic Health and Medicine

Conference

\begin{tabular}{|c|c|c|c|c|c|}
\hline Topic & Meaning unit & Code & Sub category & Category & Theme \\
\hline $\begin{array}{l}\text { During this } \\
\text { online } \\
\text { learning, the } \\
\text { lecturer } \\
\text { always } \\
\text { invites } \\
\text { students to } \\
\text { read Al- } \\
\text { Quran? }\end{array}$ & $\begin{array}{ll}1 . & \text { some } \\
& \text { lecturers } \\
& \text { always start } \\
& \text { with reading } \\
& \text { Al-Quran } \\
2 . & \text { Not all } \\
& \text { lecturers, } \\
& \text { one or two I } \\
\text { think } & \text { several } \\
\text { 3. } & \text { lecturers } \\
\text { invite their } \\
\text { students to } \\
\text { read Al- } \\
\text { Quran }\end{array}$ & $\begin{array}{l}\text { 1. There are only a } \\
\text { few lecturers } \\
\text { 2. Only a few } \\
\text { lecturers start } \\
\text { learning by } \\
\text { reading Al-Quran } \\
\text { 3. several lecturers } \\
\text { invite students to } \\
\text { read Al-Quran } \\
\text { 4. There are only a } \\
\text { few lecturers }\end{array}$ & $\begin{array}{l}\text { invitation to read } \\
\text { Al-Quran }\end{array}$ & $\begin{array}{l}\text { Online } \\
\text { learning } \\
\text { process }\end{array}$ & $\begin{array}{l}\text { Perception } \\
\text { of interest } \\
\text { in learning }\end{array}$ \\
\hline
\end{tabular}

The impact of learning is that students feel less interested in learning, less effective, and less understanding. From a physical point of view, eye fatigue is felt, from facilities and infrastructure students feel signal barriers when doing online learning from parental support to support online learning and from Islamic practice in the learning process carried out by several lecturers, in terms of decreased motivation to learn students experience decreased motivation to learn, in terms of student satisfaction, they are not satisfied and want offline learning.

"Interest is the attitude of a person's soul including the three functions of his soul (cognition, conation, and emotion), which are focused on something and in that relationship a strong element of feeling. Meanwhile, according to Djaali (2008: 121) "interest is a sense of preference and a sense of interest in a thing or activity, without anyone telling".

Interview results: "So far, I think it's effective, thank God, the targets have been achieved. Can be more productive", "I am personally effective but it is not as much as face-to-face learning which can be more active in class. And so far, my expectations in learning outcomes are quite satisfactory or have reached the target" this is in line with research from "Not effective because since covid has not been effective, it has even become ineffective because of many tasks"

This is in line with his research (Jamil, Aprilisanda. 2020). The results show that internet use attitudes, perceptions, experiences, financial conditions have a significant effect on student interest in learning. While the ability to learn independently does not have a significant effect on student interest in learning during online lectures. From some of the opinions above, it can be concluded that the notion of interest is a sense of interest, attention, more desire that someone has for something, without any encouragement.

Perception is a person's activity in assessing and understanding objects around him by using the senses he already has so that what has been understood through these senses they can respond. (Setiawan, 2013) 
E-ISSN: 2808-5361 http://e-journal.fkmumj.ac.id/
Proceeding The First

Muhammadiyah Internasional-

Public Health and Medicine

Conference

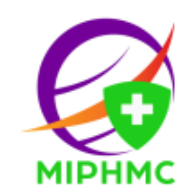

Interview results: "I prefer offline because I don't experience internet connection barriers and can meet friends directly on campus", "Both of them like it. If you are offline, you can meet friends directly, you can be active and more flexible. If you go online, you don't need to be tired and tired of going to campus", "Over time I prefer to be online, rather than offline.

Positive interview results were obtained on students' perceptions about online learning. This is in line with research (maulana \& hamidi.2020) which shows that students' perceptions of online learning in practical courses are positive, with details of teaching and learning aspects of $66.4 \%$, capability aspects (lecturers' abilities) of $74.6 \%$, and aspects of facilities. and infrastructure by $72.7 \%$.

As for the response of students' perceptions by choosing offline lectures, this is in line with research (Ningsih, 2020) the majority of students, namely $93.5 \%$ prefer offline learning in face-toface classes compared to online learning. This is mostly due to the limitations of students to provide internet quota continuously, understanding of the material is not optimal and limited interaction.

Motivation comes from the Latin word, namely "movere" which means encouragement or driving force. According to Fillmore H. Standford in the book Mangkunegara (2017: 93) says that "motivation is an energizing condition of the organism that services direct that organism toward the goal of a certain class.

Interview results: "Experienced a decrease in learning motivation", "Had felt down but not for long. After that, I got back up", "When I started online learning, I felt my motivation to study was decreasing because of the monotony and the many assignments given"

student learning motivation is also influential in the success of learning. This is following what was expressed by (Emda, 2018) that the learning process will achieve success if students have good learning motivation. Therefore, learning motivation is very important for every student, both intrinsic and extrinsic motivation.

The role of parents is very important in determining the success of their children's education. The main roles and responsibilities, among others, can be realized by guiding the continuity of children studying at home following the programs that have been studied by children in learning schools. (Khalimah, 2020)

Parent participation is required in the online school process. In short, parents are teachers, representing the school, at home where they play a role in administering learning from the stage of children doing assignments, reporting assignments, to taking online exams (Cahana, 2020)

Interview result: "My parents always ask if I have morning class or not. As well as giving an alarm when I have a morning class. My parents sometimes like to buy internet packages for me to study when I run out of internet quota", "My parents always ask if the data package is still available 
E-ISSN: 2808-5361 http://e-journal.fkmumj.ac.id/
Proceeding The First

Muhammadiyah Internasional-

Public Health and Medicine

Conference

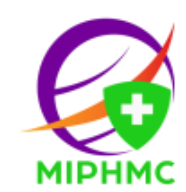

or not. Then if you are sleeping, you will also want to have class." "Alhamdulillah, my parents always support me no matter what, wherever and whatever the conditions and situations are"

The results of the interview show that the importance of parental support for children's learning, especially during the current COVID-19 pandemic. Parents play an important role in welcoming the success of their children's education, especially during online learning the role of parents is needed such as teaching children to learn and assisting children to learn, providing a comfortable atmosphere so that children focus on learning, encouraging children so that children want to learn, providing facilities to learn, directing children according to the talents and interests of each child. (Khalimah, 2020)

In the perspective of religion (Islam) learning is an obligation for every individual who believes to acquire knowledge to improve the degree of their lives which Allah SWT will raise several degrees to people who believe and have knowledge. (Sakilah, 2013 )

Interview results: "Not hindered because there is time in the afternoon for the midday prayer, but sometimes there are lecturers who like to exceed their study hours and have to pray at the next learning hour", "Alhamdulillah I always pray even though online learning is not a barrier", " Not hindered because there is time" "not hindered because I usually adjust and manage the time well between prayer and lectures"

From the results of the interview, online learning is not something that can hinder the obligation of religious people to worship, especially during this covid-19 pandemic, despite the government's ban on praying in mosques to reduce the transmission of the covid-19 virus. (Widiyani, 2020) The importance of worship is one of which makes His servants good and useful in the world for religion, humans, and the universe both from the afterlife with the reward of heaven and an abundance of goodness, on the other hand, people who are reluctant to carry out worship and do not care about all God's commands and His Messenger, then God threatened him with a painful torment. (Sudarsono, 2018 )

\section{CONCLUSIONS AND SUGGESTIONS}

Based on the results of research that has been done, online learning affects students' interest in learning. Because students get bored easily when online learning takes place, learning is less interesting unlike classroom learning, therefore lecturers must create interesting online learning and increase student interest in learning. The way to foster interest in learning in students is by providing learning motivations to students with positive words and building students in learning conditions, it can also be by paying attention to students during online learning.

Suggestions for researchers, lecturers, and parents always motivate students and their children so as not to get bored quickly in the online learning process. For lecturers, they can create interesting 
Volume I Tahun 2021

November 2021
E-ISSN: 2808-5361 http://e-journal.fkmumj.ac.id/
Proceeding The First Muhammadiyah InternasionalPublic Health and Medicine Conference

learning and always pay attention to students in the online learning process that takes place. Parents also provide comfort in learning, not always forcing children to study and also seeing the situation and condition of the child. And always give positive and constructive words for children's learning enthusiasm.

\section{REFERENCES}

Aprilisanda, Jamil. 2020. Pengaruh pembelajaran daring terhadap minat belajar mahasiswa pada masa pandemik covid-19. BAJ(Behavioral Accounting Journal)Vol. 3, No. 1, Juni 2020eISSN: 2615-7004.

Emda, Amna. "Kedudukan motivasi belajar siswa dalam pembelajaran.” Lantanida Journal 5, no. 2 (2018): 172-182.

Cahana, Nana. 2020. Pembelajaran Daring dan Peran Ganda Orang tua. Kompasiana.

Hj, Sakila, M.P.d. 2013. Belajar dalam Perspektif Islam. Menara, Vol. 12 No. 2 Juli - Desember 2013

Khalimah,nur. 2020. PERAN ORANG TUA DALAM PEMBELAJARAN DARING DI MI DARUL ULUM PEDURUNGANKOTA SEMARANG TAHUN PELAJARAN 2020/2021. Skripsi INSTITUT AGAMA ISLAM NEGERI (IAIN) SALATIGA.

Maulana,atmam. Hamidi,Muhammad. 2020. Persepsi Mahasiswa terhadap Pembelajaran Daring pada Mata Kuliah Praktik di Pendidikan Vokasi. Equilibrium: Jurnal Pendidikan Vol. VIII. Issu 2. Juni-Desember 2020

Ningsih, sulia. 2020. PERSEPSI MAHASISWA TERHADAP PEMBELAJARAN DARING PADA MASA PANDEMI COVID-19. jinotep vol 7 (2) (2020): 124-132 doi: 10.17977/um031v7i22020p124 jinotep (jurnal inovasi teknologi pembelajaran) kajian dan riset dalam teknologi pembelajaran.

Sudarsono, "Pendidikan Ibadah Perspektif Al-Qur'an dan Hadist", Jurnal Studi Keislaman, Vol. 4, No. 1, tahun 2018, hlm. 64

Widiyani, Romsha. 2020. 5 Ibadah yang Bisa Dilakukan saat Harus di Rumah untuk Cegah Virus Corona. https://news.detik.com/berita/d-4951212. Ditinjau pada 29/06/2021.

Asrul and Afil, M. (2020) 'Dampak pembelajaran online terhadap minat belajar siswa pada masa pandemi covid-19', Publikasi Ilmiah Universitas Muhammadiyah Kendari, pp. 1-15.

Dzalila, L., Ananda, A. and Zuhri, S. (2020) 'Pengaruh Pembelajaran Daring Pada Masa Pandemi Covid-19 Terhadap Tingkat Pemahaman Belajar Mahasiswa', Jurnal Signal, 8(2), p. 203. doi: 10.33603/signal.v8i2.3518.

Handayani, G. W., Maula, L. H. and Uswatun, D. A. (2020) Analisis Proses Pelaksanaan Pembelajaran Daring Di Sekolah Dasar Pada Masa Pandemi Covid 19, DIKDAS MATAPPA: Jurnal Ilmu Pendidikan Dasar. doi: 10.31100/dikdas.v3i2.649. 
Volume I Tahun 2021 November 2021
E-ISSN: 2808-5361 http://e-journal.fkmumj.ac.id/
Proceeding The First Muhammadiyah InternasionalPublic Health and Medicine Conference

Jatmoko, D. and Faizun, M. (2020) 'Persepsi Mahasiswa Terhadap Pelayanan Pembelajaran Online di Masa Pandemi Covid-19', Jurnal Pendidikan Surya Edukasi (JPSE), 6(1), pp. 104-113. doi: 10.37729/jpse.v6i1.6495.

KBBI (2021) minat, 2021. Available at: https://kbbi.web.id/minat.

Lutfiyanti (2019) 'minat belajar', Journal of Chemical Information and Modeling, 53(9), pp. 16891699.

Priyastuti, M. T. and Suhadi, S. (2020) 'Kepuasaan Mahasiswa terhadap Pembelajaran Daring Selama Pandemi Covid-19', Journal of Language and Health, 1(2), pp. 49-56. doi: 10.37287/jlh.v1i2.383.

sangadah, khotimatus (2020a) 'hubungan pelaksanaan pembelajaran daring dengan minat belajar siswa MI', Orphanet Journal of Rare Diseases, 21(1), pp. 1-9.

sangadah, khotimatus (2020b) 'pembelajaran online pada masa pandemi covid-19', Orphanet Journal of Rare Diseases, 21(1), pp. 1-9.

Simbolon, N. (2014) 'Faktor Faktor Yang Mempengaruhi Minat Belajar Peserta Didik', Elementary School Journal Pgsd Fip Unimed, 1(2), pp. 14-19.

Swasta, B. (2011) 'Organisasi Persepsi', Convention Center Di Kota Tegal, 4(80), p. 22. Available at: http://eprints.dinus.ac.id/19103/10/bab2_18450.pdf.

WHO (2021) Novel Corona Virus yang dapat di akses pada : https://www.who.int/indonesia/news/novel-coronavirus/qa/qa-for-public

Asrul and Afil, M. (2020) 'Dampak pembelajaran online terhadap minat belajar siswa pada masa pandemi covid-19', Publikasi Ilmiah Universitas Muhammadiyah Kendari, pp. 1-15.

Dzalila, L., Ananda, A. and Zuhri, S. (2020) 'Pengaruh Pembelajaran Daring Pada Masa Pandemi Covid-19 Terhadap Tingkat Pemahaman Belajar Mahasiswa', Jurnal Signal, 8(2), p. 203. doi: 10.33603/signal.v8i2.3518.

Handayani, G. W., Maula, L. H. and Uswatun, D. A. (2020) Analisis Proses Pelaksanaan Pembelajaran Daring Di Sekolah Dasar Pada Masa Pandemi Covid 19, DIKDAS MATAPPA: Jurnal Ilmu Pendidikan Dasar. doi: 10.31100/dikdas.v3i2.649.

Jatmoko, D. and Faizun, M. (2020) 'Persepsi Mahasiswa Terhadap Pelayanan Pembelajaran Online di Masa Pandemi Covid-19', Jurnal Pendidikan Surya Edukasi (JPSE), 6(1), pp. 104-113. doi: 10.37729/jpse.v6i1.6495.

KBBI (2021) minat, 2021. Available at: https://kbbi.web.id/minat.

Lutfiyanti (2019) 'minat belajar', Journal of Chemical Information and Modeling, 53(9), pp. 16891699. 
Volume I Tahun 2021

November 2021
E-ISSN: 2808-5361 http://e-journal.fkmumj.ac.id/
Proceeding The First Muhammadiyah InternasionalPublic Health and Medicine

Conference

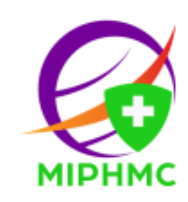

Priyastuti, M. T. and Suhadi, S. (2020) 'Kepuasaan Mahasiswa terhadap Pembelajaran Daring Selama Pandemi Covid-19', Journal of Language and Health, 1(2), pp. 49-56. doi: 10.37287/jlh.v1i2.383.

sangadah, khotimatus (2020a) 'hubungan pelaksanaan pembelajaran daring dengan minat belajar siswa MI', Orphanet Journal of Rare Diseases, 21(1), pp. 1-9.

sangadah, khotimatus (2020b) 'pembelajaran online pada masa pandemi covid-19', Orphanet Journal of Rare Diseases, 21(1), pp. 1-9.

Simbolon, N. (2014) 'Faktor Faktor Yang Mempengaruhi Minat Belajar Peserta Didik', Elementary School Journal Pgsd Fip Unimed, 1(2), pp. 14-19.

Swasta, B. (2011) 'Organisasi Persepsi', Convention Center Di Kota Tegal, 4(80), p. 22. Available at: http://eprints.dinus.ac.id/19103/10/bab2 18450.pdf. 
Volume I Tahun 2021

November 2021
E-ISSN: 2808-5361

http://e-journal.fkmumj.ac.id/
Proceeding The First Muhammadiyah InternasionalPublic Health and Medicine

Conference 